\title{
Erratum to: Investigating the micromechanical evolutions within inherently anisotropic granular materials using discrete element method
}

\author{
Ehsan Seyedi Hosseininia
}

Published online: 25 August 2012

(C) Springer-Verlag 2012

Erratum to: Granular Matter

DOI 10.1007/s10035-012-0340-5

Owing to an unfortunate technical error, this article appeared with an incorrect year of publication in the credit line, which was given as "Granular Matter (2007) 14:483-503". The correct credit line is as follows:

Granular Matter (2012) 14:483-503

The publisher sincerely apologizes for this mistake.

The online version of the original article can be found under doi: 10.1007/s10035-012-0340-5.

E. Seyedi Hosseininia ( $\square)$

Civil Engineering Department, Faculty of Engineering,

Ferdowsi University of Mashhad, P.O. Box: 91775-1111,

Mashhad, Iran

e-mail: eseyedi@um.ac.ir 